\title{
Professionals' Feedback on the PEFC Fair Supply Chain Project Activated in Italy after the "Vaia" Windstorm
}

\author{
Francesco Negro ${ }^{1, *}$, Omar Espinoza ${ }^{2}$, Antonio Brunori ${ }^{3} \oplus$, Corrado Cremonini ${ }^{1}$ and Roberto Zanuttini ${ }^{1}$ \\ 1 Department of Agricultural, Forest and Food Sciences (DISAFA), University of Torino, Largo Paolo Braccini 2, \\ 10095 Grugliasco, Italy; corrado.cremonini@unito.it (C.C.); roberto.zanuttini@unito.it (R.Z.) \\ 2 Department of Bioproducts and Biosystems Engineering (UMN-BBE), University of Minnesota, \\ 2004 Folwell Ave., St. Paul, MN 55108, USA; espinoza@umn.edu \\ 3 PEFC Italia, Via Pietro Castellini 17-Int. 6, 06135 Perugia-Ponte San Giovanni, Italy; info@pefc.it \\ * Correspondence: francesco.negro@unito.it
}

check for

updates

Citation: Negro, F.; Espinoza, O.; Brunori, A.; Cremonini, C.; Zanuttini, R. Professionals' Feedback on the PEFC Fair Supply Chain Project Activated in Italy after the "Vaia" Windstorm. Forests 2021, 12, 946. https://doi.org/10.3390/f12070946

Academic Editors: Michele Brunetti, Michela Nocetti and

Alexander Petutschnigg

Received: 11 June 2021

Accepted: 14 July 2021

Published: 17 July 2021

Publisher's Note: MDPI stays neutral with regard to jurisdictional claims in published maps and institutional affiliations.

Copyright: (c) 2021 by the authors. Licensee MDPI, Basel, Switzerland. This article is an open access article distributed under the terms and conditions of the Creative Commons Attribution (CC BY) license (https:/ / creativecommons.org/licenses/by/ $4.0 /)$.

\begin{abstract}
In the fall of 2018, the "Vaia" windstorm grounded around 8.5 million $\mathrm{m}^{3}$ of timber in northeastern Italy. Soon after, the Programme for the Endorsement of Forest Certification (PEFC) Italy activated a project called "fair supply chain" to promote the purchase of timber from the damaged areas at a reasonable price. The initiative was addressed at forest owners, forest and processing enterprises, retailers, and supporting organizations. This study reports the results of a survey performed to assess the effectiveness of the project two years after its launch. The survey, in the form of a questionnaire submitted to all adhering organizations, investigated different aspects such as motivations for adherence to the project, satisfaction with the project, sale of the labeled material, and promotion of the specific label. The results provide a detailed outline of the above aspects. Through the various findings, the project is perceived as effective in supporting the region, enhancing an organizations' image, and limiting price fall. Yet, further efforts should be aimed at increasing networking and business opportunities. Some recommendations are also offered for similar projects in the future, as forest disturbances are increasing worldwide in frequency and intensity due to climate change.
\end{abstract}

Keywords: forest disturbances; forest owners and enterprises; label; supply chain; timber assortments; timber market; windstorm; wooden products

\section{Introduction}

In the fall of 2018, the "Vaia" windstorm grounded around 8.5 million $\mathrm{m}^{3}$ of timber, mainly spruce and silver fir, in northeastern Italy [1,2]. This event strongly impacted the forest-wood sector of the area, resulting in changes to timber harvesting, processing, and the market [3,4]. In the months after the storm, the Italian agency of the Programme for the Endorsement of Forest Certification (PEFC) activated a specific "fair supply chain" project (Figure 1), taking advantage of its know-how in forest certification. PEFC is the most widespread forest certification in Italy, with a total certified forest area of around 880,000 ha (around $8 \%$ of the national forest area) and with around 1200 Chain of Custody $(\mathrm{CoC})$ certifications [5]. The amount of certified national forest remains limited compared to that of many other European countries [6]; however, it can be expected to grow given the positive growth trends at the national and global levels [7].

The primary objective of the project was to promote the purchase of timber from the damaged areas to mitigate the economic and social drawbacks of the storm [8]. Typically, windstorms and other forest disturbances strongly decrease the price of timber involved, even in the case of low-damaged stands [9].

The PEFC fair supply chain project is managed by PEFC-Italy, which also coordinates, through accredited certification bodies, audits of the adhering organizations and takes care of communication aspects. A specific website (www.filierasolidalepefc.it, accessed 
on 11 June 2021) was activated to promote the initiative. According to the procedural guidelines [10], adherence to the PEFC fair supply chain is restricted to Italian enterprises only, with the purpose of sustaining the local forest-wood sector. Four categories of participants are included:

- Forest owners (including without PEFC certification) who possess timber, of any amount and type, from the areas subjected to the windstorm. They must: (i) have logging authorization based on the appropriate regional regulations, and (ii) communicate the size of each lot to be sold, which shall have a volume of less than $10,000 \mathrm{~m}^{3}$ of timber;

- $\quad$ First buyers include forest and processing enterprises, along with retailers. They are either PEFC CoC-certified, or if not, by adhering to the fair supply chain, they can benefit from favored economic conditions to obtain certification. First buyers are required to purchase timber from the areas subjected to the storm in amounts equal to at least $50 \%$ of their annual timber need or at least $10,000 \mathrm{~m}^{3}$. In any case, they shall not buy a single lot larger than $5000 \mathrm{~m}^{3}$;

- Italian companies of the wood sector must be PEFC CoC-certified and can use the PEFC fair supply chain label if (i) they purchase timber from suppliers involved in the fair supply chain, and (ii) they put the label on products consistent with the input material;

- Supporting organizations, such as commerce associations and forest consortia, can adhere freely. They are only required to promote the PEFC fair supply chain, for instance, by organizing workshops.

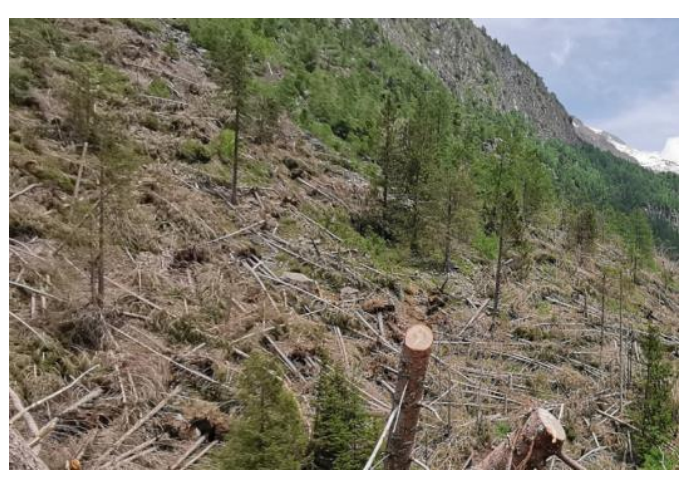

(a)

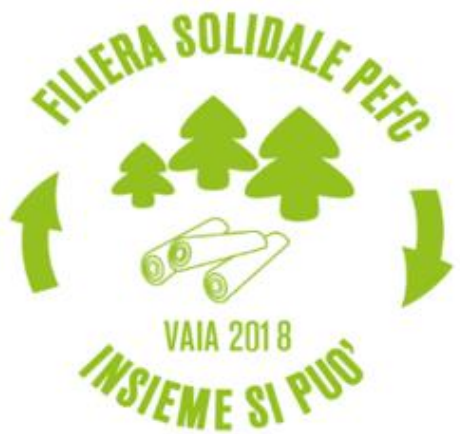

(b)

Figure 1. The Vaia windstorm strongly impacted forests in northeastern Italy. (a) Trees of an entire mountainside grounded by the windstorm; (b) Label of the PEFC fair supply chain, made of various elements: images of trees and logs represent this specific forest-wood supply chain; the top and bottom text ("PEFC fair supply chain" and "Together we can") is ethically-focused; the central text ("Vaia 2018") identifies the windstorm; the arrows suggest the role of the "fair supply chain", with adhering organizations and purchasers together engaged in supporting the impacted areas.

To date, 124 organizations adhere to the PEFC fair supply chain, of which 38 are forest owners (mainly regions, provinces, and municipalities), 37 are first buyers or companies of the wood sector (forest enterprises, sawmills, manufacturers of packaging or of engineered wood-based products such as furniture, and others), and 49 are supporting organizations (forest consortia, associations, universities, and others).

The total amount of timber traded within the PEFC fair supply chain is not exactly known at present. As a general overview, the roundwood assortments comprise several wood species (spruce, silver fir, pine, larch, beech) ranging from logs for beams to firewood. The products realized vary within a broad choice as well, including, for instance, structural timber, wooden packaging, parquet flooring, and design objects. The amount of material harvested, processed, or traded by each adhering enterprise ranges from a few dozen to more than $5000 \mathrm{~m}^{3}$ [8], reflecting the fact that different types of organizations adhere to this initiative. Overall, the PEFC fair supply chain can be considered an innovative example of labeling intended to valorize timber and to promote its ethical commerce; further, harvested 
wood products from the area also contribute to limiting overall carbon losses [11]. The outreach of the initiative is relevant as well since it covers the local, national, and partly international scales.

The objective of this study was to assess the effectiveness of the PEFC fair supply chain two years after its launch. To this end, a survey was conducted by submitting a questionnaire to all adhering organizations. Surveys are effective tools to assess the perceptions of forest owners, enterprises, and other subjects operating in the forest-wood sector and to evaluate the outcomes of projects compared to expectations. Recently, Schneider et al. [12] investigated the forest stakeholders' perceptions of Natura2000 network in the Czech Republic, Kronholm et al. [13] studied family forest owners' perceptions of management and thinning operations in young dense forests in Sweden, and Gamache et al. [14] assessed professional consumers' perceptions of thermally-treated wood in the USA.

Overall, the present study provides an increased understanding of the effectiveness of the PEFC fair supply chain. It also presents information useful for developing similar initiatives to valorize timber coming from damaged areas. These could be useful in various circumstances in the future since forest disturbances are increasing worldwide in frequency and intensity [15].

\section{Materials and Methods}

For the purpose of this study, an online questionnaire was submitted to organizations adhering to the PEFC fair supply chain. The questionnaire was developed taking as a general reference the methods adopted in a recent study by Gamache et al. [14].

\subsection{Sample Frame and Questionnaire Development}

The target audience consisted of all 124 organizations adhering to the PEFC fair supply chain, namely, forest owners, first buyers, companies of the wood sector, and supporting organizations (see Introduction). The questionnaire was developed through an iterative process. It was firstly drafted considering the aim of the study, a literature review, and knowledge needs expressed by PEFC-Italy. After various fine-tuning rounds among the authors, the first draft was submitted to six industry professionals. Modifications were made based on the feedback received.

The final draft consisted of 22 questions that addressed three areas: registration data, activity within the PEFC fair supply chain, and perceptions of the project. The final questionnaire was transferred into Google Forms software (Google LLC, Mountain View, CA, USA). Prior to submitting it to organizations, the proper working of online compilation and response collection was double-checked. Table 1 provides a brief outline of the questionnaire, whereas the full version is included in Appendix A.

Table 1. Outline of the questionnaire.

\begin{tabular}{|c|c|c|}
\hline Information Collected & Question Number and Content & Scale of Measurement \\
\hline Registration data & $\begin{array}{l}\text { Organization name, Respondent's position, 1. Area } \\
\text { of activity, 8. Already PEFC certificate holder }\end{array}$ & Open-ended questions \\
\hline $\begin{array}{l}\text { Activity within the PEFC fair } \\
\text { supply chain }\end{array}$ & $\begin{array}{l}\text { 2. Organization category, 9.-10. Type of labeling } \\
\text { (roundwood/sawn wood/products), 12.-13. Label } \\
\text { promotion methods, i.e., who and how, 16.-17. Sale } \\
\text { of labeled material, i.e., customer type and location }\end{array}$ & None \\
\hline Perceptions & $\begin{array}{l}\text { 3.-3.1 Motivations for adherence, } 4 .-5 \text {. Satisfaction } \\
\text { with label effectiveness, } 6 \text {. Feedback received, } 7 \text {. } \\
\text { How the initiative was discovered, } 11 \text {. Effect on sale } \\
\text { price, 14.-15. Effectiveness of promotion, } 18 \text {. } \\
\text { Customer's receptivity, 19. Label contribution to } \\
\text { enhancing the organization's image, 20. Competition } \\
\text { from non-labeled material, } 21 \text {. Major obstacle to } \\
\text { commercializing, 22. Comments and suggestions }\end{array}$ & $\begin{array}{l}\text { Likert importance scale (e.g., } 1=\text { "not } \\
\text { important at all", } 5=\text { "very important") } \\
\text { Likert scale of attribute content (e.g., } \\
1=\text { "not contributed at all", } 5=\text { "highly } \\
\text { contributed") } \\
\text { Open-ended questions }\end{array}$ \\
\hline
\end{tabular}




\subsection{Survey Implementation and Data Analysis}

The questionnaire was sent via email to all adhering organizations. The distribution list was compiled using the PEFC-Italy list of adhering organizations. One initial invitation was sent, followed by three reminders. Data were automatically collected by the software; after closing the survey, they were downloaded and analyzed.

Descriptive statistics, including averages, standard deviations, and counts, were completed through Microsoft Excel (Microsoft Corp., Redmond, WA, USA). Inferential statistics to test for significant differences were performed through SPSS 27.0 (IBM Corp., Armonk, NY, USA). The chi-square goodness-of-fit test was used to compare the category distribution of respondents with that of all adhering organizations, and to compare grouped responses from all respondents with expected uniform distributions of responses. Significant differences were assessed through standardized residual (SR) analysis [16]. Associations between organizations' categories and responses were assessed by the Fischer exact test, considering that statistically expected frequencies (EFs) in various cells were lower than those required by the chi-square test of independence. Significant differences were assessed by adjusted standardized residual (ASR) analysis [16]. Significance was always set at a level of 0.05 .

\subsection{Study Limitations}

As usual in surveys, there are limits to the methods and outcomes of this study. Responding organizations may have been affected by self-selection bias, and differences may exist between them and the overall population of adhering organizations. Sending the questionnaire via email may have resulted in a bias related to the type of responding organizations. These may have been more familiar with the use of informatics tools and somehow more dynamic in participating in the system. Adhering organizations joined the project at different times. Therefore, those adhering longer may have been more aware of the effectiveness of the action.

Due to the above limitations, extending the outcomes of the study to all adhering organizations was not possible. However, it is the opinion of the authors that the study is useful for providing a broad understanding of the effectiveness of the PEFC fair supply chain.

\section{Results}

\subsection{Description of Respondents}

Overall, 69 responses were collected, corresponding to a $56 \%$ response rate. As for respondents' categories, 24 are forest owners (34.8\%), 17 enterprises and retailers $(24.6 \%)$, and 28 supporting organizations $(40.6 \%)$. They mainly operate and sell in the area affected by the windstorm, but in some cases, also at national and international levels. No significant differences were found between their category distribution and that of all adhering organizations $\left(\chi^{2}=1.031, p\right.$-value $\left.=0.597\right)$.

Figure 2 shows the percentage of respondents who already held a PEFC certification when they joined the initiative: $88 \%$ of forest owners, $82 \%$ of enterprises and retailers, and $7 \%$ of supporting organizations.

Regarding the information sources for the PEFC fair supply chain initiative, $65 \%$ of respondents first came to know about the initiative through the PEFC communication network (Figure 3). The first information from different sources was mainly related to regional forest services (23\%) and public institutions $(19 \%)$, whereas other ways of receiving information (customers, friends, etc.) were far less common (19\% altogether).

Significant differences were found in the frequencies of sources from which the initiative was first discovered by the respondents $\left(\chi^{2}=86.172, p\right.$-value $\left.<0.001\right)$. SR analysis showed that compared to the EFs, PEFC communication was by far the most prevalent way of coming to know about the initiative. Information from regional forest services and public institutions matched the EFs, whereas other channels (customers, friends, etc.) were significantly less represented. No significant differences were found between respondents ${ }^{\prime}$ categories and ways of coming to know about the initiative $\left(\chi^{2}=11.003, p\right.$-value $\left.=0.297\right)$. 


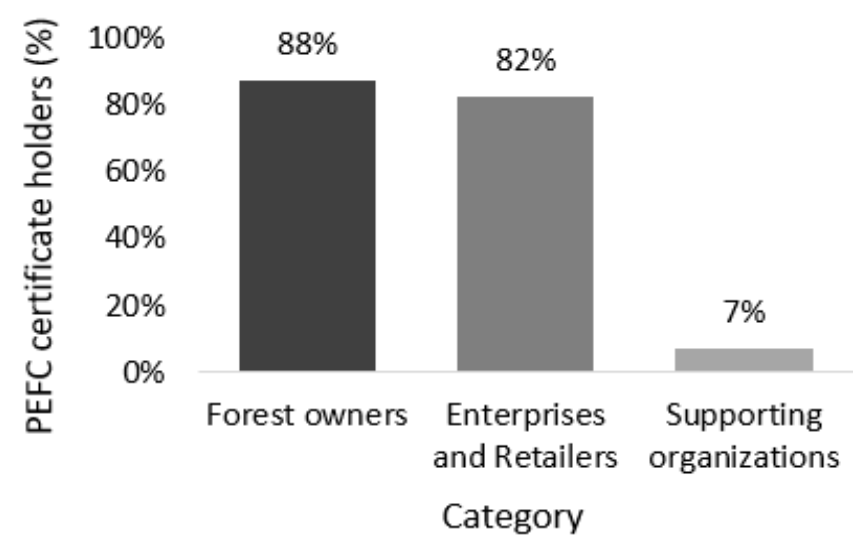

Figure 2. Percentage of respondents who already held a PEFC certification when they joined the initiative.

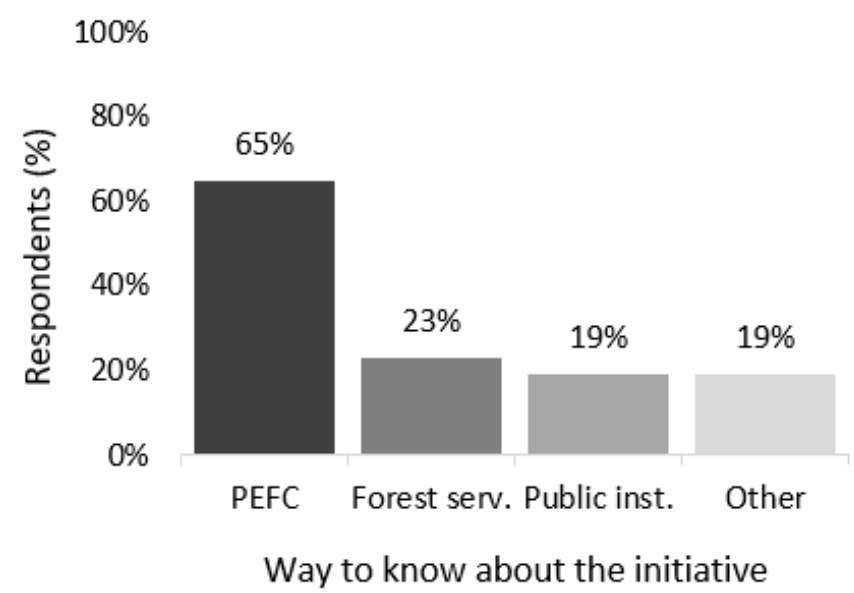

Figure 3. Sources from which responding organizations came to know about the PEFC fair supply chain (total is $>100 \%$ because multiple responses were allowed).

\subsection{Reasons for Adhering and Satisfaction}

Figure 4 shows that the highest-rated reason for adhering to the PEFC fair supply chain was, by far, to "Support the area" (82.6\% of respondents rated it "Very important" or "Important"). In descending-rate order, other reasons were "Marketing" (44.9\%), "Networking" (37.7\%), to "Find new customers" (31.9\%), and to "Avoid a price fall" (30.4\%). The majority of non-responses came from supporting organizations. Table 2 shows the outcomes of the related statistical analysis.

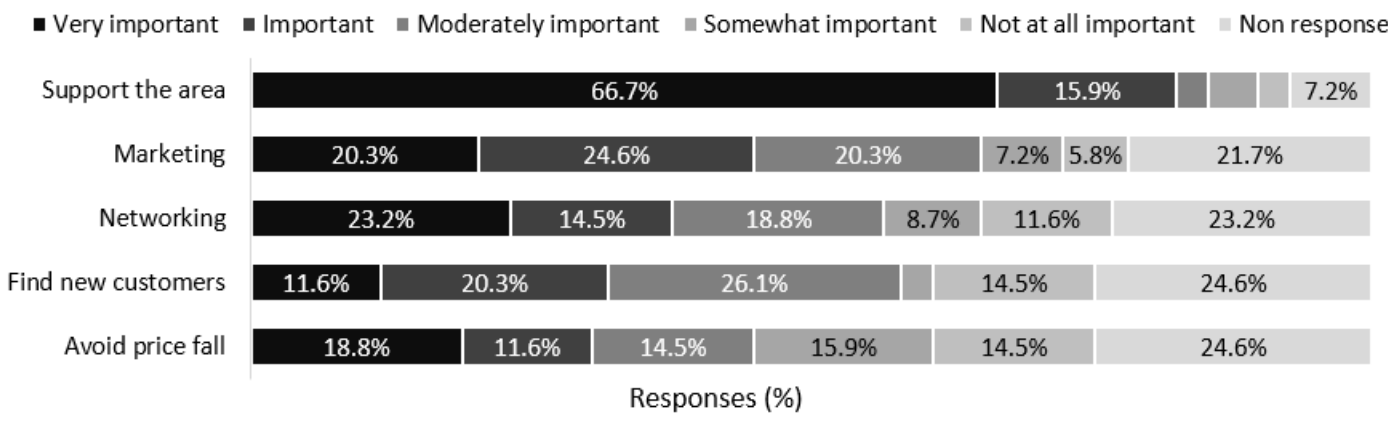

Note: percentages below 5\% are not shown; characteristics on the left are sorted by "Very important" and "Important" ratings, with the largest percentage at the top.

Figure 4. Importance of the reasons why respondents adhered to the PEFC supply chain; $N=69$. 
Table 2. Reasons for adhering to the system. Goodness of fit test: Comparison of grouped responses from all respondents with expected uniform distributions of responses. Fischer's exact test: Associations between organizations' categories and reasons' ratings. Significance set at a level of 0.05.

\begin{tabular}{ccccc}
\hline & \multicolumn{2}{c}{ Goodness-of-Fit Test } & \multicolumn{2}{c}{ Fischer's Exact Test } \\
Reason & $\chi^{\mathbf{2}}$ & $\boldsymbol{p}$-Value & $\chi^{\mathbf{2}}$ & $\boldsymbol{p}$-Value \\
\hline Avoid price fall & 1.269 & 0.867 & 9.046 & 0.332 \\
Networking & 5.962 & 0.202 & 11.994 & 0.131 \\
Marketing & 12.852 & 0.012 & 10.607 & 0.184 \\
Find new customers & 14.154 & 0.007 & 7.192 & 0.511 \\
Support the area & 112.094 & $<0.001$ & 18.826 & 0.001 \\
\hline
\end{tabular}

SR analysis showed that compared to the EFs, respondents placed significant, high importance on the supporting role of the initiative, moderate to high importance on marketing, and moderate importance on the opportunity to find new customers. ASR analysis showed that compared to the EFs, supporting organizations and forest owners placed significantly more importance on the supporting role of the action.

Figure 5 shows the satisfaction with the effectiveness of the initiative. The highest satisfaction was with the capacity of the initiative to "Support the area" (53.6\% of respondents rated it "very satisfied" or "satisfied"), followed by "Marketing purposes" (29.0\%), "Networking (23.2\%)", support to "Find new customers" (17.4\%), and to "Avoid a price fall" (15.9\%). The majority of non-responses came from supporting organizations. Table 3 shows the outcomes of the related statistical analysis.

\begin{tabular}{|c|c|c|c|c|c|c|c|c|}
\hline \multirow{2}{*}{$\begin{array}{r}\text { Support the area } \\
\text { Marketing }\end{array}$} & \multicolumn{2}{|r|}{$29.0 \%$} & \multicolumn{2}{|c|}{$24.6 \%$} & \multicolumn{2}{|c|}{$27.5 \%$} & $7.2 \%$ & $10.1 \%$ \\
\hline & $8.7 \%$ & $20.3 \%$ & \multicolumn{2}{|r|}{$37.7 \%$} & & $8.7 \%$ & \multicolumn{2}{|c|}{$21.7 \%$} \\
\hline Networking & $10.1 \%$ & $13.0 \%$ & $23.2 \%$ & $11.6 \%$ & $11.6 \%$ & & \multicolumn{2}{|c|}{$30.4 \%$} \\
\hline Find new customers & \multicolumn{2}{|c|}{$14.5 \%$} & & $13.0 \%$ & $10.1 \%$ & & \multicolumn{2}{|l|}{$33.3 \%$} \\
\hline Avoid price fall & \multicolumn{2}{|c|}{$11.6 \%$} & & $10.1 \%$ & $14.5 \%$ & & \multicolumn{2}{|l|}{$31.9 \%$} \\
\hline
\end{tabular}

Note: percentages below 5\% are not shown; characteristics on the left are sorted by "Very satisfied" and

"Satisfied" ratings, with the largest percentage at the top.

Figure 5. Satisfaction with the effectiveness of the initiative; $N=69$.

Table 3. Satisfaction with the effectiveness of the system. Goodness of fit test: Comparison of grouped responses from all respondents with expected uniform distributions of responses. Fischer's exact test: Associations between organizations' categories and reasons' ratings. Significance set at a level of 0.05.

\begin{tabular}{ccccc}
\hline & \multicolumn{2}{c}{ Goodness-of-Fit Test } & \multicolumn{2}{c}{ Fischer's Exact Test } \\
Reason & $\chi^{\mathbf{2}}$ & $\boldsymbol{p}$-Value & $\chi^{\mathbf{2}}$ & $\boldsymbol{p}$-Value \\
\hline Avoid price fall & 15.021 & 0.005 & 10.948 & 0.156 \\
Networking & 5.542 & 0.236 & 15.224 & 0.035 \\
Marketing & 33.778 & $<0.001$ & 7.404 & 0.487 \\
Find new customers & 14.652 & 0.005 & 6.542 & 0.607 \\
Support the area & 24.774 & $<0.001$ & 14.777 & 0.031 \\
\hline
\end{tabular}

SR analysis showed that compared to the EFs, satisfaction with the ability to "Support the area" was significantly high, whereas satisfaction with "Marketing", "Finding new customers", and "Avoiding a price fall" was significantly moderate. ASR analysis showed, compared to the EFs, a significantly lower number of forest owners rating high satisfaction 
with the ability to "Support the area"; as for "Networking", enterprises and retailers were significantly less satisfied than expected.

Figure 6 illustrates how much respondents perceived that adhering to the PEFC fair supply chain contributed to enhancing their image. Organizational images described as "Attentive to sustainability" and "Ethical" scored the highest ratings (63.8\% and 63.7\% of respondents deemed there to be a very high/high contribution to these, respectively), followed by "Attentive to our country" (50.7\%). Table 4 shows the outcomes of the related statistical analysis.

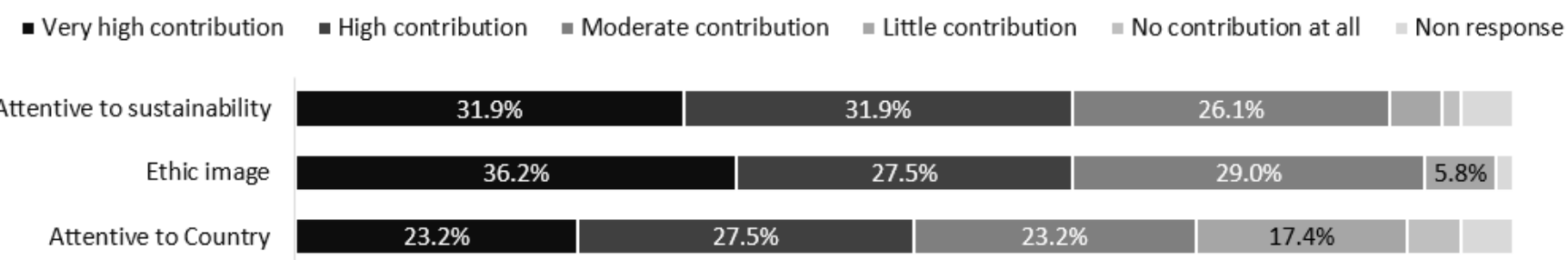

Percent of respondents

Note: percentages below $5 \%$ are not shown; characteristics on the left are sorted by "Very high contribution" and "High contribution" ratings, with the largest percentage at the top.

Figure 6. Respondents' perceptions of the role of the initiative in enhancing their image; $N=69$.

Table 4. Respondents' perceptions of the role of the initiative in enhancing their image. Goodness of fit test: Comparison of grouped responses from all respondents with expected uniform distributions of responses. Fischer exact test: Associations between organizations' categories and reasons' ratings. Significance set at a level of 0.05 .

\begin{tabular}{ccccc}
\hline & \multicolumn{2}{c}{ Goodness-of-Fit Test } & \multicolumn{2}{c}{ Fischer Exact Test } \\
Image Enhancement & $\chi^{\mathbf{2}}$ & $\boldsymbol{p}$-Value & $\chi^{2}$ & $\boldsymbol{p}$-Value \\
\hline Ethical image & 14.471 & 0.002 & 14.620 & 0.014 \\
Attentive to sustainability & 32.636 & $<0.001$ & 20.029 & 0.002 \\
Attentive to our country & 11.723 & 0.019 & 16.451 & 0.021 \\
\hline
\end{tabular}

SR analysis showed that compared to the EFs, rating "No contribution at all" was significantly less represented in all attributes, and rating "Little contribution" was significantly less represented in the "Ethical" and "Attentive to sustainability" categories. ASR analysis showed that compared to the EFs, the rating "Very high contribution" given by forest owners was significantly less represented in all attributes, and that their rating of "Attentive to sustainability" was significantly shifted towards a moderate contribution. The rating of enterprises and retailers was significantly shifted towards a moderate contribution in "Attentive to our country". Supporting organizations' ratings of "Ethical image" and "Attentive to sustainability" were significantly oriented towards "Very high contribution".

\subsection{Selling of Labeled Material}

Labeled material was sold by respondents to forest and processing enterprises, retailers, and final customers. Purchasers were mainly located in northeastern Italy-that is, the area affected by the storm - but in some cases, also in several other Italian regions and in other countries. The roundwood assortments sold were single assortments without any classification $(29 \%)$, short butt-logs $(14 \%)$, beams $(11 \%)$, and packaging $(13 \%)$. The most common species were spruce and silver fir $(53 \%)$, followed by larch $(22 \%)$, beech $(20 \%)$, and pine $(5 \%)$. The semifinished and finished products most commonly sold were beams including scantlings and laths $(27 \%)$, boards $(17 \%)$, chips $(15 \%)$, finished products $(13 \%)$, firewood (8\%), and poles (6\%).

Figure 7 shows how respondents described the price of their PEFC fair supply chain labeled material compared to the price of similar, non-labeled products sold by them. The 
most frequent perception level was, by far, "Similar" (87\%). The majority of "Not applicable to our organization" responses came from supporting organizations.

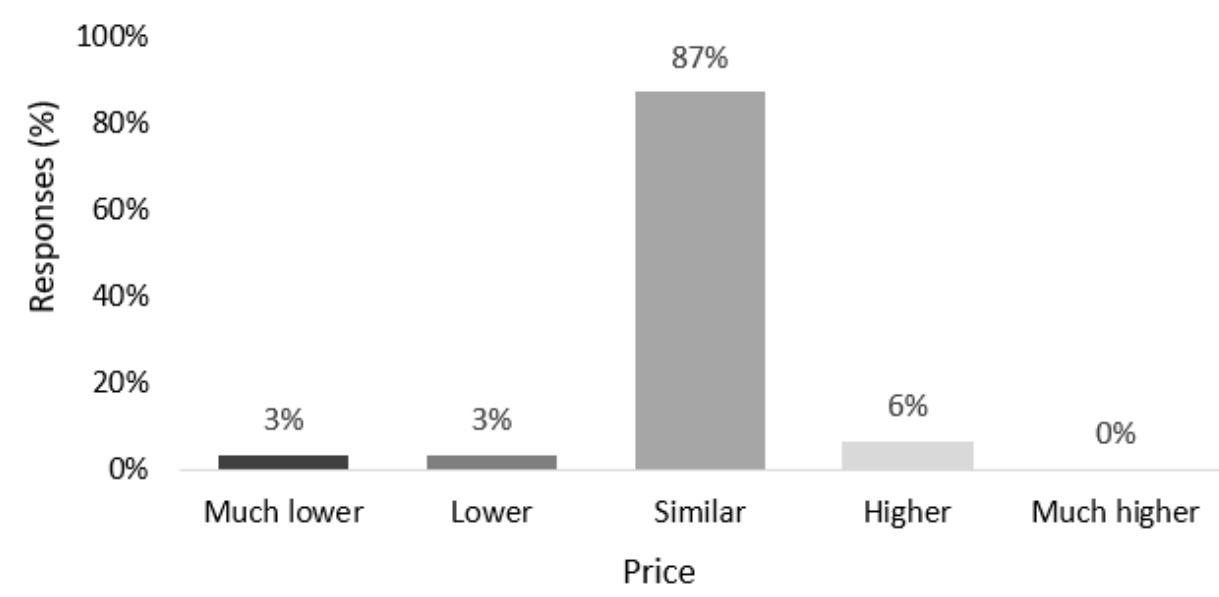

Figure 7. Sale price of PEFC Fair supply chain labeled products compared to similar, non-labeled products sold by respondents.

Significant differences were found in the described prices $\left(\chi^{2}=63.839, p\right.$-value $\left.<0.001\right)$. SR analysis showed that compared to the EFs, a "Similar price" rating was significantly over-represented, whereas other ratings were significantly under-represented. As for associations between respondents' categories and sale prices, no significant differences were found $\left(\chi^{2}=3.949, p\right.$-value $\left.=0.969\right)$.

Figure 8 illustrates how respondents rated receptivity towards their label by customers located in regions affected by the storm compared to customers from other regions. The most frequent rating was "Similar" (37.7\%), followed by "Higher" (27.5\%) and "Much higher" $(15.9 \%)$.

- Much higher $\quad$ - Higher $\quad$ Similar $\quad$ Lower $\quad$ Much lower $\quad$ Non response

\begin{tabular}{|l|l|l|l|l|l|}
\hline Customers receptivity & $15.9 \%$ & $27.5 \%$ & $37.7 \%$ & $10.1 \%$ & $7.2 \%$ \\
\hline
\end{tabular}

\section{Responses (\%)}

Figure 8. Perception on receptivity to the label shown by customers in the regions affected by the storm compared to customers in other regions; $N=69$.

Significant differences were found in the perception of customers' receptivity $\left(\chi^{2}=30.375\right.$, $p$-value $<0.001)$. SR analysis showed that compared to the EFs, the number of "Similar" receptivity ratings was significantly higher, and that a "Much lower" receptivity rating was significantly less represented. Significant differences were found when associating an organization's category with its perception of customers' receptivity $\left(\chi^{2}=16.826\right.$, $p$-value $=0.013$ ). ASR analysis showed that compared to the EFs, forest owners' ratings of "Lower receptivity" were higher than expected, and that enterprises and supporting organizations' ratings of "Similar receptivity" were higher than expected.

The survey also investigated respondents' perceptions of competition set by semifinished products and end-products made of timber coming from the windstorm that are not labeled by the PEFC fair supply chain. These products are currently available on the market from producers that independently activated marketing actions to valorize timber coming from the area. Figure 9 illustrates that the most frequent perception levels were "No competition" (28\%), "Low competition" (23\%), and "Not aware" (23\%). The majority of "Not applicable to our organization" responses came from supporting organizations. 


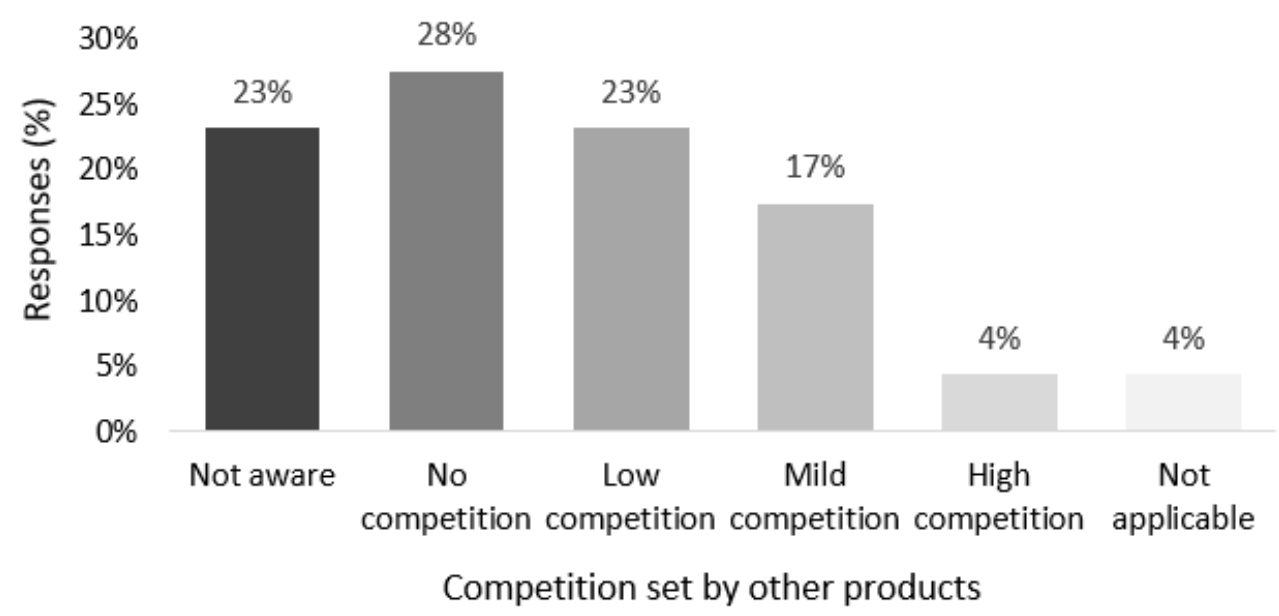

Figure 9. Respondents' perceptions of competition set by semifinished products and end-products made of timber coming from the windstorm that are not labeled PEFC Fair supply chain.

Significant differences were found in the perceptions of competition set by the above semifinished products and end-products $\left(\chi^{2}=50.333, p\right.$-value $\left.<0.001\right)$. SR analysis showed that compared to the EFs, the number of organizations "Not aware" of such products was significantly higher than expected, and that the ratings of "High", "Mild", and "Low competition" were significantly less represented. No significant differences were found between respondents' categories and perceptions of competition $\left(\chi^{2}=3.949, p\right.$-value $\left.=0.969\right)$.

\subsection{Promotion of the Label}

Figure 10 lists the subjects who carried out the promotion activity. The most frequent channels were the organizations themselves (37.0\%) and PEFC-Italy (35.0\%).

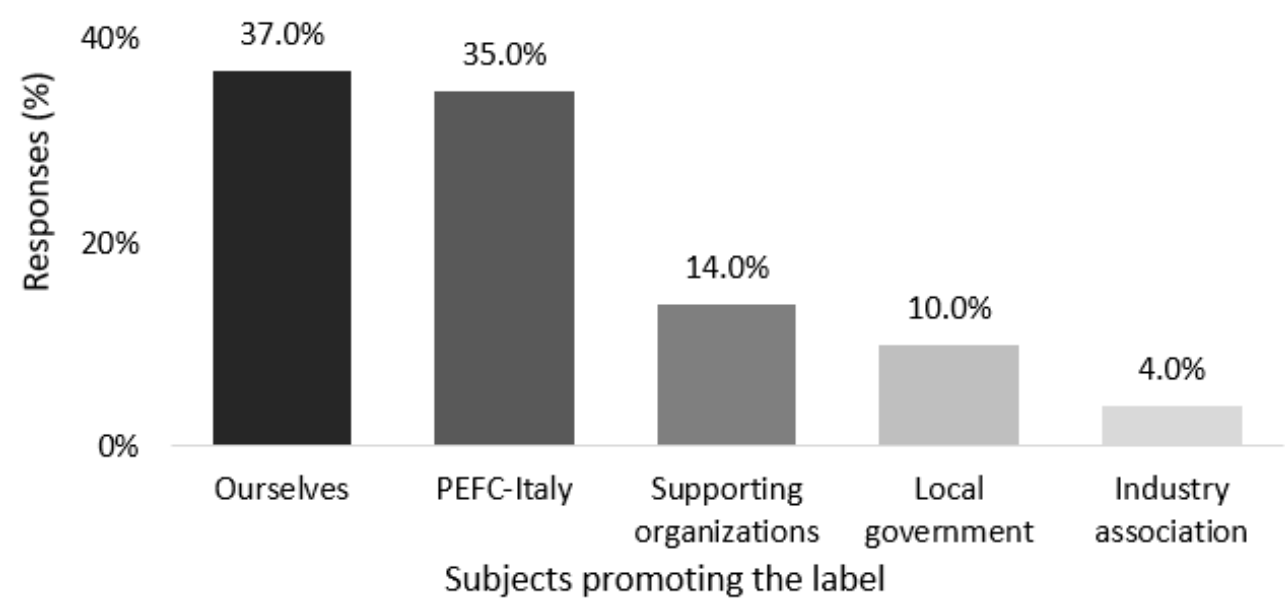

Figure 10. Subjects promoting the label as declared by respondents.

Significant differences were found in the subjects to whom respondents entrusted the promotion $\left(\chi^{2}=45.300, p\right.$-value $\left.<0.001\right)$. SR analysis showed that compared to the EFs, respondents relied significantly more on themselves and on PEFC-Italy, and significantly less on the "Local government" and "Industry associations". Significant differences were found in associations between respondents' categories and promotion entrustment $\left(\chi^{2}=17.456, p\right.$-value $\left.=0.014\right)$. ASR analysis showed that compared to the EFs, forest owners relied significantly more on the local government, enterprises on industry associations, and supporting organizations on themselves.

Figure 11 summarizes the methods used by respondents to promote the initiative. The most frequent methods were posting on websites (used by $24.3 \%$ of respondents), sending 
emails $(22.2 \%)$, posting on social media (17.4\%), and communicating at public events such as fairs (17.4\%). Seven organizations did not promote it, 24 used one promotional method, 14 used two methods, and 24 used three or more methods.

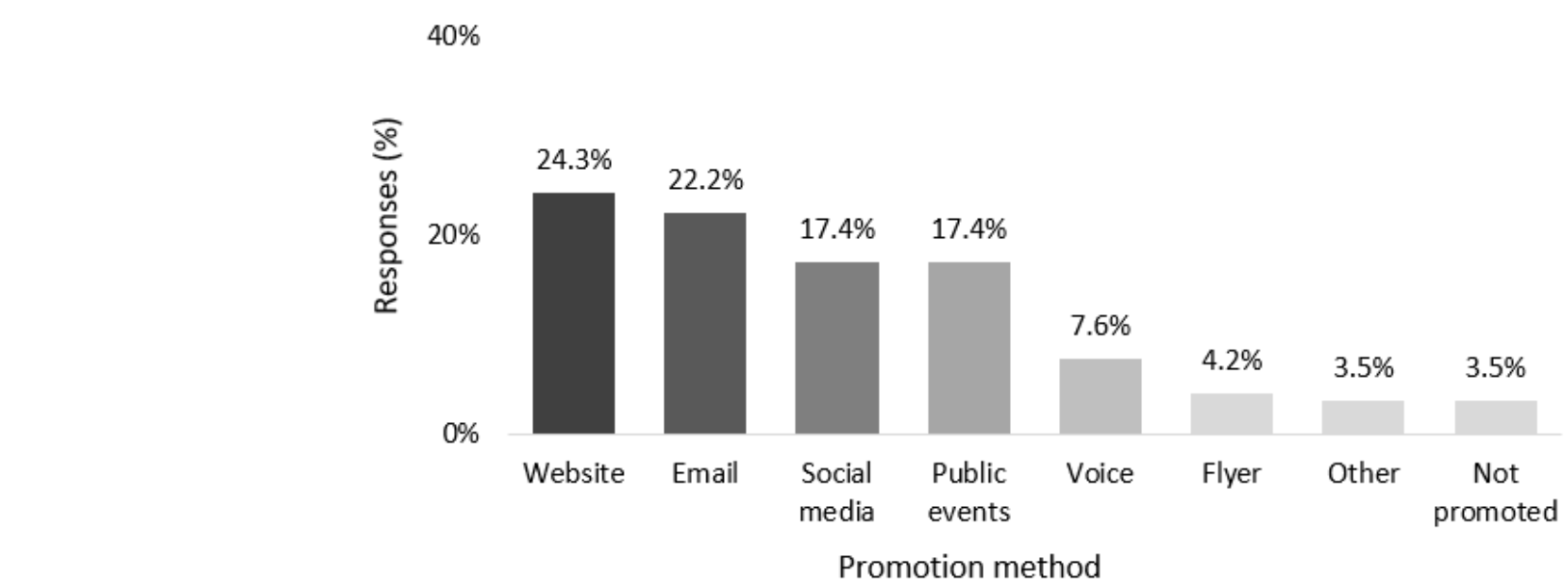

Figure 11. Methods used by respondents to promote the initiative.

Significant differences were found in the choice of promotional methods $\left(\chi^{2}=61.890\right.$, $p$-value $<0.001)$. SR analysis showed that compared to the EFs, the numbers of respondents promoting the initiative by "Emails" and "Websites" were significantly higher than expected, and that those promoting it by "Flyers", "Other methods", or "Not promoting it" were significantly lower. No significant differences were found when associating organizations' categories and promotional methods $\left(\chi^{2}=17.810, p\right.$-value $\left.=0.171\right)$.

Figure 12 reports respondents' perceptions of the effectiveness of their promotional activities with reference to the subjects to whom these were addressed. Public institutions and forest owners gave the highest ratings (27.5\% each for "Very effective" and "Effective" ratings). The majority of non-responses came from supporting organizations.

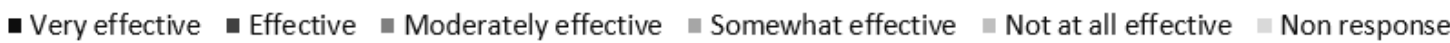

\begin{tabular}{|c|c|c|c|c|c|c|}
\hline Public institutions & $5.8 \%$ & $23.2 \%$ & $7.2 \%$ & & & $40.6 \%$ \\
\hline Forest owners & $24.6 \%$ & $33.3 \%$ & & 5.89 & $3 \% \quad 7.2 \%$ & $26.1 \%$ \\
\hline Customers & $17.4 \%$ & $30.4 \%$ & $7.2 \%$ & $5.8 \%$ & & $34.8 \%$ \\
\hline Forest enterprises & $18.8 \%$ & $36.2 \%$ & & $5.8 \%$ & $8.7 \%$ & $27.5 \%$ \\
\hline Retailers & $14.5 \%$ & $37.7 \%$ & & $7.2 \%$ & $5.8 \%$ & $30.4 \%$ \\
\hline Processing enterprises & $13.0 \%$ & $43.5 \%$ & & & & $33.3 \%$ \\
\hline Other organizations & $8.7 \%$ & $34.8 \%$ & $8.7 \%$ & & & $42.0 \%$ \\
\hline
\end{tabular}

Percent of respondents

Note: percentages below $5 \%$ are not shown; characteristics on the left are sorted by "Very effective" and "Effective" ratings, with the largest percentage at the top.

Figure 12. Respondents' perceptions of the effectiveness of their promotional activities with reference to the subjects to whom these were addressed; $N=69$.

Table 5 shows the outcomes of the related statistical analysis. 
Table 5. Respondents' perceptions of the effectiveness of their promotional activities with reference to the subjects to whom these were addressed. Goodness of fit test: Comparison of grouped responses from all respondents with expected uniform distributions of responses. Fischer's exact test: Associations between organizations' categories and reasons' ratings. Significance set at a level of 0.05.

\begin{tabular}{ccccc}
\hline & \multicolumn{2}{c}{ Goodness-of-Fit Test } & \multicolumn{2}{c}{ Fischer's Exact Test } \\
Subjects & $\chi^{2}$ & $\boldsymbol{p}$-Value & $\chi^{\mathbf{2}}$ & $\boldsymbol{p}$-Value \\
\hline Public institutions & 33.608 & $<0.001$ & 12.146 & 0.070 \\
Forest owners & 35.000 & $<0.001$ & 11.703 & 0.091 \\
Customers & 62.478 & $<0.001$ & 4.960 & 0.869 \\
Forest enterprises & 38.042 & $<0.001$ & 6.408 & 0.630 \\
Retailers & 22.556 & $<0.001$ & 9.021 & 0.295 \\
Processing enterprises & 22.780 & $<0.001$ & 12.486 & 0.063 \\
Other organizations & 42.250 & $<0.001$ & 10.004 & 0.165 \\
\hline
\end{tabular}

SR analysis showed that compared to the EFs, responses were significantly shifted towards "Moderately effective" for all attributes.

\section{Discussion}

\subsection{Description of Respondents, Reasons to Adhere, and Satisfaction}

The response rate $(56 \%)$ can be considered satisfactory given that surveys in the forest products sector typically achieve rates of about 26-30\% [17]. The high participation registered can be attributed in part to the limited number of subjects (124) mostly operating in a well-defined area and connected by adherence to a clearly focused system. For various questions, the majority of non-responses came from supporting organizations; given their role, several of these entities likely chose not to rate attributes related to commercial purposes.

The sizeable proportion of forest owners and enterprises already holding PEFC certification (Figure 2) is consistent with the certification's wide diffusion in the area affected by the storm. Likewise, the low percentage of supporting organizations already certified is not surprising given that they are generally not involved in timber commerce.

The ways by which the initiative came to be known (Figure 3) revealed that the communication efforts of PEFC-Italy played a pivotal role. If similar initiatives are to be activated in the future, managing authorities should be aware of the relevance of their communication efforts. For instance, Michal et al. [18] indicated that knowledge by consumers and interested parties is key to the effectiveness of forest certification, so that it can be a real means of achieving sustainability. In this vein, communication should be performed to share information with stakeholders using long-term strategies aimed at consistency [19].

The survey also indicated that effective support to make the system known can be sought by forest services and public institutions. Supporting organizations adhering to the system can provide valuable contributions as well, so they should be involved in communication from the very beginning of their adherence.

Supporting the area was clearly the main reason to adhere (Figure 4), with supporting organizations and forest owners placing great importance on this aspect. This might be expected given that the role of supporting organizations is specifically oriented toward support and considering that forest owners particularly needed support as they were the most affected by the windstorm. Some value was also placed by respondents on marketing purposes and the opportunity to find new customers. This reflects the fact that accessing new markets is a relevant driver that compels forest companies to adopt sustainable forest certifications [20].

The satisfaction with the supporting role of the certification was high (Figure 5), which is a valuable outcome since that was a key reason for organizations to adhere. The limited satisfaction with its supporting role expressed by forest owners could be explained by the extent of the damage they suffered, which can hardly be compensated by any supporting 
measure. According to the replies collected, the managing authority should address its next effort at increasing networking and business opportunities [21]. Various strategies can be identified in this view, and based on some replies collected through the "Why were you not satisfied?" open-ended question. For instance, networking strategies could include organizing common events, setting up a reserved page on the project website to facilitate the interaction of organizations, and disseminating contacts, expertise, and possible linkages.

Overall, respondents perceived moderate-to-very-high contributions in image enhancement (Figure 6). This can be considered a relevant added value of the initiative, especially because the attention paid by customers to the social aspects of using wood is increasing [22]. It is also conceivable that perceptions of contributions to enhancing "Attentiveness to sustainability" and an "Ethical image" not only derive from the initiative per se but also from the fact that the managing authority, PEFC, is commonly associated with such concepts [23]. Image enhancement is one of the main benefits that companies expect when adopting sustainable forest certifications [24]. The lower ratings for "Attentive to our country" presumably indicate that, even if the windstorm affected various Italian regions, respondents mainly view the initiative as supporting them on a local scale. Supporting organizations' ratings of "Ethical image" and "Attentive to sustainability" were significantly weighted towards a "Very high contribution". This presumably indicates that such organizations see the initiative as highly in line with their type of activity.

\subsection{Sale of Labeled Materials and Promotions}

The sale price of labeled products was deemed mainly "similar" to that of comparable, non-labeled ones (Figure 7). Therefore, the initiative has presumably been quite effective in limiting a price fall (at least in business-to-customer transactions), which is known to be a major issue after natural disturbances [9]. This outcome is also quite consistent with respondents' satisfaction with "Avoiding a price fall". In any case, these must be considered as broad indications; detailed studies on prices, assortments, wood species, and markets should be performed to better investigate the magnitude of this effect. The effects of forest certification on the market (for instance, competitive or barrier effects), vary depending on several aspects, among which are countries and wood products [25].

In addition, some responses to open-ended questions revealed that, in certain cases, the initiative had a negative rebound on the sale price. Some respondents, in fact, stated that a certain number of purchasers interpreted the provenance from the windstorm as an indication of low timber quality. This was consistent with other open-ended responses stating that the main obstacles to commercializing timber coming from the windstorm are misperceptions and a general lack of knowledge. Consequently, it can be suggested that the managing authority should make efforts to educate professionals and customers outside the fair supply chain. The quality of timber coming from natural disturbances, in fact, is not necessarily low, as it is often perceived. It depends on the intensity of the disturbance to which timber was subjected and the time elapsed after the event, which is related to wood degradation [9].

The receptivity of customers in the area impacted by the storm was generally perceived by respondents as "similar" to that of customers in other regions (Figure 8). As might be expected, "Much lower" receptivity from customers in the area impacted by the storm was significantly less common. The "Lower" receptivity indicated by forest owners could derive from the fact that they could have higher expectations of the receptivity of local buyers. However, comparisons among customers in different regions are difficult to make given that organizations mainly operate at a local-regional level.

The perceived competition by similar, non-labeled products (Figure 9) was limited, with many organizations "not aware" of them. This could reveal that attempts to valorize the timber coming from the windstorm led by single producers, even if valuable, have a somewhat limited diffusion. Therefore, it is conceivable that adhering to this common, structured system offers higher opportunities. 
Respondents indicated that the label was mainly promoted by themselves and by PEFC-Italy (Figure 10). Few organizations (14\%) relied on promotion performed by supporting organizations; therefore, links between these subjects can be encouraged. The initiative was mainly promoted through communications on websites and by email (Figure 11), showing that these methods are nowadays widespread among the forest sector of the area. Such promotions were, in general, "moderately effective" (Figure 12), which indicates that further effort to better communicate the initiative is required even two years after the activation of the project. This is consistent with the abovementioned need to set long-term communication and marketing strategies.

\subsection{Indications for Similar Systems to Be Activated in the Future}

Based on the outcomes of this survey, some suggestions can be formulated for similar initiatives that could be activated in the future to support forest-wood supply chains impacted by large forest disturbances:

- The managing authority should place high importance on its communication efforts, which is key to create awareness, and communication and promotion should be consistent over time;

- The local-regional dimension should be treated as fundamental, even in the case of large disturbances affecting several regions;

- Creating networking and business opportunities is a relevant aspect that should be pursued by means of appropriate strategies;

- Specific initiatives should be addressed at forest owners, as the subjects most impacted by the disruptive event;

- Support to promote the system should be sought by public institutions, who should try to involve supporting organizations from the very beginning;

- The ethical image gained by adhering to the project and the increased attention of final customers should be used as relevant arguments to convince organizations to adhere;

- Promotions should aim at increasing the knowledge among professionals and customers of timber coming from forest disturbances: its quality is generally considered low, but this is not necessarily the case as the quality depends on several factors;

- Performing a survey among the adhering organizations sometime after the beginning of the project should be planned as a useful tool for continuous improvement.

Clearly, the above suggestions are indicative and must be adjusted based on the specific situation in terms of the extent of the disturbance, area impacted, timber assortments and conservation, supply chains involved, and other factors.

\section{Conclusions}

The PEFC fair supply chain can be considered an innovative example of valorization of timber recovered from forest disturbances. The survey of adhering organizations showed that the system is effective in supporting the area impacted by the Vaia windstorm. Results can also be used by the managing authority to improve the system, particularly in terms of increasing networking and business opportunities. Finally, the outcomes of this study can be taken as a reference to activate similar projects in the future. This could prove useful given that the frequency and intensity of forest disturbances are increasing.

Author Contributions: Conceptualization, F.N. and O.E.; methodology, F.N., O.E., A.B., C.C., and R.Z.; formal analysis, F.N. and O.E.; investigation, F.N and O.E.; data curation, F.N.; writing-original draft preparation, F.N.; writing-review and editing, F.N., O.E., A.B., C.C., and R.Z.; supervision, F.N. All authors have read and agreed to the published version of the manuscript.

Funding: This research received no external funding.

Data Availability Statement: The raw data presented in this study are available on request from the corresponding author (francesco.negro@unito.it). 
Acknowledgments: Tiziano Delpero is thanked for his support in submitting the questionnaire to the organizations.

Conflicts of Interest: The authors declare no conflict of interest.

\section{Appendix A}

The following is the full questionnaire submitted to organizations adhering to the PEFC fair supply chain.

\section{WELCOME TO THE PEFC FAIR SUPPLY CHAIN QUESTIONNAIRE.}

This survey aims to assess the efficacy of the label "PEFC fair supply chain" activated at the beginning of 2019. Understanding what worked and what did not is relevant to improving the management of the label and for proposing similar initiatives that could be needed in the future. The questionnaire is being submitted to you because we consider your feedback relevant to the outcomes of the study.

Completing this questionnaire will take approximatively $15 \mathrm{~min}$. Participation in this survey is voluntary and the information gathered will be kept strictly confidential. Results will be reported anonymously and in an aggregate manner. At the end of the study, you will receive a report about the results. By completing this questionnaire, you agree that the information you provide will be used as described above.

In case of doubts or for any clarification, please contact Antonio Brunori, Secretary General of PEFC-Italy (info@pefc.it), or Francesco Negro, Researcher at DISAFA, University of Torino (francesco.negro@unito.it).

We thank you in advance for your collaboration and for the time that you will dedicate to completing the questionnaire.

Enterprise/Organization:

Respondent's position in the enterprise/organization:

\begin{tabular}{|l|l|}
\hline 1 & In which Italian regions or countries does you company \\
& usually sell? (mark all that apply) \\
\hline & $\square$ Friuli Venezia Giulia \\
& $\square$ Trentino-Alto Adige \\
& $\square$ Veneto \\
& $\square$ Lombardia \\
& $\square$ Other northern regions \\
& $\square$ Central Italy \\
& $\square$ Southern Italy \\
& $\square$ France \\
& $\square$ Switzerland \\
& $\square$ Austria \\
& $\square$ Slovenia \\
& $\square$ Other countries \\
& $\square$ Not applicable to our enterprise/organization \\
\hline
\end{tabular}

\begin{tabular}{|l|l|}
\hline 2 & $\begin{array}{l}\text { What is the role of your enterprise/organization in the PEFC } \\
\text { fair supply chain? (mark all that apply) }\end{array}$ \\
\hline & $\square$ Forest owner \\
& $\square$ Forest operation enterprise \\
& $\square$ Processing enterprise \\
& $\square$ Trader/retailer \\
& $\square$ Supporting organization \\
& $\square$ Other: \\
\hline
\end{tabular}




\begin{tabular}{|l|l|l|}
\hline \multirow{3}{*}{3} & \multicolumn{2}{|l|}{$\begin{array}{l}\text { Why did you adhere to the PEFC fair supply chain? [rate from 1 (reason not } \\
\text { important at all) to 5 (very important reason)] }\end{array}$} \\
\hline \multirow{4}{*}{ A } & To avoid a price fall & 12345 \\
\cline { 2 - 3 } & For marketing purposes & 12345 \\
\cline { 2 - 3 } & To enter a network of related enterprises & 12345 \\
\cline { 2 - 3 } & To find new customers/markets & 12345 \\
\cline { 2 - 3 } & To support the area after the storm & 12345 \\
\cline { 2 - 3 } & Other: & 12345 \\
\hline
\end{tabular}

\begin{tabular}{|c|l|}
\hline 3.1 & $\begin{array}{l}\text { If in the previous question, you rated the "other" option, } \\
\text { what are you referring to? }\end{array}$ \\
\hline A & Open-ended answer \\
\hline
\end{tabular}

\begin{tabular}{|l|l|l|}
\hline \multirow{4}{*}{4} & $\begin{array}{l}\text { How much are you satisfied with the effectiveness of the label/initiative? [rate } \\
\text { from 1 (very dissatisfied) to 5 (very satisfied)] If you had no expectation for a } \\
\text { certain option, leave the field blank. }\end{array}$ \\
\hline \multirow{4}{*}{ A } & To avoid a price fall & 12345 \\
\cline { 2 - 3 } & For marketing purposes & 12345 \\
\cline { 2 - 3 } & To enter a network of related enterprises & 12345 \\
\cline { 2 - 3 } & To find new customers/markets & 12345 \\
\cline { 2 - 3 } & To support the area after the storm & 12345 \\
\cline { 2 - 3 } & Other: & 12345 \\
\hline
\end{tabular}

\begin{tabular}{|c|l|}
\hline 5 & $\begin{array}{l}\text { If you assigned } 1 \text { or } 2 \text { (very dissatisfied or dissatisfied) to certain } \\
\text { options in the previous question, why are you not satisfied? }\end{array}$ \\
\hline A & Open-ended answer \\
\hline
\end{tabular}

\begin{tabular}{|l|l|}
\hline 6 & $\begin{array}{l}\text { Did you receive any positive or negative feedback from your } \\
\text { customers/commercial partners concerning the label/initiative? }\end{array}$ \\
\hline A & Open-ended answer \\
\hline
\end{tabular}

\begin{tabular}{|l|l|}
\hline 7 & $\begin{array}{l}\text { How did you learn about the existence of the label/initiative, PEFC fair } \\
\text { supply chain? (mark all that apply) }\end{array}$ \\
\hline & $\square$ Press release \\
& $\square$ PEFC communication \\
& $\square$ Forest service \\
& $\square$ Organizations (region, university, trade/industry association, etc.) \\
& $\square$ A client who asked for it \\
A & $\square$ A colleague \\
& $\square$ A friend \\
& $\square$ Other:
\end{tabular}

\begin{tabular}{|c|l|}
\hline 8 & $\begin{array}{l}\text { Was your enterprise/organization a PEFC certificate holder before } \\
\text { joining the PEFC fair supply chain? }\end{array}$ \\
\hline A & $\begin{array}{l}\square \text { Yes } \\
\square \text { No }\end{array}$ \\
\hline
\end{tabular}




\begin{tabular}{|c|c|c|c|c|c|}
\hline 9 & \multicolumn{5}{|c|}{$\begin{array}{l}\text { Which roundwood assortments did you label, or described in the invoice as } \\
\text { labeled? (for each assortment, mark all species that apply: } \mathrm{S}=\text { spruce and silver } \\
\text { fir; } \mathrm{B}=\text { beech; } \mathrm{L}=\text { larch; } \mathrm{P}=\text { pine) }\end{array}$} \\
\hline \multirow{9}{*}{ A } & $\begin{array}{l}\text { Single assortment, } \\
\text { without any } \\
\text { classification }\end{array}$ & $\square S$ & $\square \mathrm{B}$ & $\square \mathrm{L}$ & $\square \mathrm{P}$ \\
\hline & Short butt-logs & $\square \mathrm{S}$ & $\square \mathrm{B}$ & $\square \mathrm{L}$ & $\square \mathrm{P}$ \\
\hline & Logs for beams & $\square \mathrm{S}$ & $\square \mathrm{B}$ & $\square \mathrm{L}$ & $\square \mathrm{P}$ \\
\hline & For packaging & $\square \mathrm{S}$ & $\square \mathrm{B}$ & $\square \mathrm{L}$ & $\square \mathrm{P}$ \\
\hline & Poles & $\square \mathrm{S}$ & $\square \mathrm{B}$ & $\square \mathrm{L}$ & $\square \mathrm{P}$ \\
\hline & Pulpwood & $\square \mathrm{S}$ & $\square \mathrm{B}$ & $\square \mathrm{L}$ & $\square \mathrm{P}$ \\
\hline & Firewood & $\square \mathrm{S}$ & $\square \mathrm{B}$ & $\square \mathrm{L}$ & $\square \mathrm{P}$ \\
\hline & For chipping & $\square \mathrm{S}$ & $\square \mathrm{B}$ & $\square \mathrm{L}$ & $\square \mathrm{P}$ \\
\hline & $\begin{array}{l}\text { Not applicable to } \\
\text { our enter- } \\
\text { prise/organization }\end{array}$ & $\square S$ & $\square \mathrm{B}$ & $\square \mathrm{L}$ & $\square \mathrm{P}$ \\
\hline
\end{tabular}

\begin{tabular}{|l|l|l|l|l|l|}
\hline \multirow{3}{*}{10} & $\begin{array}{l}\text { Which sawn wood assortments/products did you label, or described in the invoice as } \\
\text { labeled? (for each assortment/product, mark all species that apply: S = spruce and } \\
\text { silver fir; } \mathrm{B}=\text { beech; } \mathrm{L}=\text { larch; P = pine) }\end{array}$ \\
\hline \multirow{5}{*}{$\begin{array}{l}\text { Beams including scantlings and } \\
\text { laths }\end{array}$} & $\square \mathrm{S}$ & $\square \mathrm{B}$ & $\square \mathrm{L}$ & $\square \mathrm{P}$ \\
\cline { 2 - 6 } $\mathrm{A}$ & Boards including small boards & $\square \mathrm{S}$ & $\square \mathrm{B}$ & $\square \mathrm{L}$ & $\square \mathrm{P}$ \\
\cline { 2 - 6 } & Poles & $\square \mathrm{S}$ & $\square \mathrm{B}$ & $\square \mathrm{L}$ & $\square \mathrm{P}$ \\
\cline { 2 - 6 } & Chips & $\square \mathrm{S}$ & $\square \mathrm{B}$ & $\square \mathrm{L}$ & $\square \mathrm{P}$ \\
\cline { 2 - 6 } & Firewood & $\square \mathrm{S}$ & $\square \mathrm{B}$ & $\square \mathrm{L}$ & $\square \mathrm{P}$ \\
\cline { 2 - 6 } & End-product & $\square \mathrm{S}$ & $\square \mathrm{B}$ & $\square \mathrm{L}$ & $\square \mathrm{P}$ \\
\cline { 2 - 6 } & $\begin{array}{l}\text { Not applicable to our } \\
\text { enterprise/organization }\end{array}$ & $\square \mathrm{S}$ & $\square \mathrm{B}$ & $\square \mathrm{L}$ & $\square \mathrm{P}$ \\
\hline
\end{tabular}

\begin{tabular}{|c|l|}
\hline 11 & $\begin{array}{l}\text { How would you describe the sale price of your PEFC fair supply chain } \\
\text { labeled products? }\end{array}$ \\
\hline \multirow{3}{*}{ A } & $\square$ Much lower compared to our other similar products \\
& $\square$ Lower compared to our other similar products \\
& $\square$ Same price as for our other similar products \\
& $\square$ Higher compared to our other similar products \\
& $\square$ Much higher compared to our other similar products \\
& $\square$ Not applicable to our organization \\
\hline
\end{tabular}

\begin{tabular}{|l|l|}
\hline 12 & Who promoted the label? (mark all that apply) \\
\hline & $\square$ Ourselves \\
& $\square$ Our industry association \\
& $\square$ The local government \\
& $\square$ PEFC \\
& $\square$ Supporting organizations that are part of the label \\
& $\square$ Other: \\
\hline
\end{tabular}

\begin{tabular}{|l|l|}
\hline 13 & How was the label promoted? (mark all that apply) \\
\hline & $\square$ By email \\
& $\square$ By word-of-mouth \\
& $\square$ By flyers \\
& $\square$ At public events (fairs, congresses, etc.) \\
A & $\square$ By posting to our website or other websites \\
& $\square$ By posting to our social media (Facebook, Twitter, etc.) \\
& $\square$ Did not actively promote it \\
& $\square$ Other: \\
\hline
\end{tabular}




\begin{tabular}{|l|l|l|}
\hline \multirow{4}{*}{14} & \multicolumn{2}{|l|}{$\begin{array}{l}\text { Considering the effort you made, please rate the effectiveness of your } \\
\text { promotional activity, in terms of the increased level of awareness of the } \\
\text { subjects listed below. [from 1 (not effective at all) to 5 (highly effective), mark } \\
\text { all categories to which your promotion was addressed] }\end{array}$} \\
\hline \multirow{4}{*}{ A } & Forest owners & 12345 \\
\cline { 2 - 3 } & Forest enterprises & 12345 \\
\cline { 2 - 3 } & First and second processing enterprises & 12345 \\
\cline { 2 - 3 } & Traders/retailers & 12345 \\
\cline { 2 - 3 } & Customers & 12345 \\
\cline { 2 - 3 } & Public institutions & 12345 \\
\cline { 2 - 3 } & $\begin{array}{l}\text { Other institutions (trade/industry } \\
\text { associations, etc.) }\end{array}$ & 12345 \\
\hline
\end{tabular}

\begin{tabular}{|c|l|}
\hline 15 & $\begin{array}{l}\text { If you assigned 1 or 2 (not effective at all or slightly effective) to some } \\
\text { options in the previous question, why was the promotion not effective? }\end{array}$ \\
\hline A & Open-ended answer \\
\hline
\end{tabular}

\begin{tabular}{|c|l|}
\hline 16 & $\begin{array}{l}\text { To which type of customer did you sell the labeled material? (mark all } \\
\text { that apply) }\end{array}$ \\
\hline & $\square$ Forest enterprises \\
& $\square$ First and second processing enterprises \\
& $\square$ Traders/retailers \\
& $\square$ Customers \\
A & $\square$ Public institutions \\
& $\square$ Other institutions (trade/industry associations, etc.) \\
& $\square$ Not applicable to our enterprise/organization \\
\hline
\end{tabular}

\begin{tabular}{|l|l|}
\hline 17 & Where are the subjects to whom you sold the labeled material located? \\
(mark all that apply)
\end{tabular}

\begin{tabular}{|c|l|}
\hline 18 & $\begin{array}{l}\text { In your opinion, were customers in the regions affected by the storm } \\
\text { more receptive to the label/initiative than customers in other regions? } \\
\text { [from } 1 \text { (much less receptive) to 5 (very much more receptive)] }\end{array}$ \\
\hline A & 12345 \\
\hline
\end{tabular}

\begin{tabular}{|l|l|l|}
\hline \multirow{3}{*}{19} & $\begin{array}{l}\text { What is your perception of how the label/initiative contributed to enhancing } \\
\text { the following images of your company? [from 1 (did not contribute at all) to 5 } \\
\text { (highly contributed)] }\end{array}$ \\
\hline \multirow{3}{*}{ A } & Ethical image & 12345 \\
\cline { 2 - 3 } & Attentive to sustainability & 12345 \\
\cline { 2 - 3 } & Attentive to our country & 12345 \\
\hline
\end{tabular}




\begin{tabular}{|l|l|}
\hline \multirow{2}{*}{20} & $\begin{array}{l}\text { On the market, there are semifinished products and end-products } \\
\text { made of timber coming from the windstorm that are NOT labeled } \\
\text { PEFC fair supply chain. Are you aware of them, and if you are, do you } \\
\text { regard them as competition? }\end{array}$ \\
\hline & $\square$ I am not aware of such other products \\
& $\square$ I am aware of them and they are no competition \\
& $\square$ I am aware of them and they are setting little competition \\
& $\square$ I am aware of them and they are setting mild competition \\
& $\square$ I am aware of them and they are setting high competition \\
& $\square$ Not applicable to our enterprise/organization \\
\hline
\end{tabular}

\begin{tabular}{|c|l|}
\hline 21 & $\begin{array}{l}\text { In your opinion, which is the major obstacle to commercializing the } \\
\text { timber coming from the Vaia storm? }\end{array}$ \\
\hline A & Open-ended answer \\
\hline
\end{tabular}

\begin{tabular}{|c|l|}
\hline 22 & $\begin{array}{l}\text { Do you have any other thoughts or suggestions you want to share } \\
\text { about the PEFC fair supply chain? }\end{array}$ \\
\hline A & Open-ended answer \\
\hline
\end{tabular}

\section{References}

1. Giannetti, F.; Pecchi, M.; Travaglini, D.; Francini, S.; D'Amico, G.; Vangi, E.; Cocozza, C.; Chirici, G. Estimating VAIA windstorm damaged forest area in Italy using time series Sentinel-2 imagery and continuous change detection algorithms. Forests 2021, 12, 680. [CrossRef]

2. Motta, R.; Ascoli, D.; Corona, P.; Marchetti, M.; Vacchiano, G. Silviculture and wind damages. The storm "Vaia.". Forest@-Rivista Selvic. Ecol. For. 2018, 15, 94-98. [CrossRef]

3. Cadei, A.; Mologni, O.; Röser, D.; Cavalli, R.; Grigolato, S. Forwarder productivity in salvage logging operations in difficult terrain. Forests 2020, 11, 341. [CrossRef]

4. Provincia Autonoma di Trento. Piano d'azione Vaia in Trentino. L'evento, gli interventi, i risultati. Sherwood 2020, 248 (Suppl. 2), 3-72.

5. Available online: https://www.pefc.it/ (accessed on 4 July 2021).

6. Maesano, M.; Ottaviano, M.; Lidestav, G.; Lasserre, B.; Matteucci, G.; Scarascia Mugnozza, G.; Marchetti, M. Forest certification map of Europe. iForest 2018, 11, 526-533. [CrossRef]

7. Fernholz, K.; Bowyer, J.; Erickson, G.; Groot, H.; Jacobs, M.; McFarland, A.; Pepke, E. Forest Certification Update 2021: The Pace of Change. Available online: https:/ / www.dovetailinc.org/portfoliodetail.php?id=60085a177dc07 (accessed on 5 July 2021).

8. Geatti, P.; Novelli, V.; Marangon, F.; Troiano, S. The birth of a new sustainability label: "Filiera solidale PEFC—Vaia 2018-Insieme si può". In AISME 2020, Salerno, Italy, 13-14 February 2020; Esposito, B., Malandrino, O., Sessa, M.R., Sica, D., Eds.; FrancoAngeli s.r.l.: Milano, Italy, 2020.

9. Negro, F.; Ascoli, D.; Garbarino, M.; Marzano, R. Impact of forest disturbances on wood quality: A review. In Renewable Resources for a Sustainable and Healthy Future, Proceedings of the 63rd International Convention of Society of Wood Science and Technology, Portorose, Slovenia (virtual conference), 12-15 July 2020; LeVan-Green, S., Ed.; SWST: Monona, WI, USA, 2020.

10. Available online: https:/ / filierasolidalepefc.files.wordpress.com/2020/08/disciplinare_filiera_solidale_pefc-1.pdf (accessed on 27 January 2021).

11. Pilli, R.; Vizzari, M.; Chirici, G. Combined effects of natural disturbances and management on forest carbon sequestration: The case of Vaia storm in Italy. Ann. For. Sci. 2021, 78, 46. [CrossRef]

12. Schneider, J.; Ruda, A.; Kalasová, Ž.; Paletto, A. The forest stakeholders' perception towards the NATURA 2000 network in the Czech Republic. Forests 2020, 11, 491. [CrossRef]

13. Kronholm, T.; Bengtsson, D.; Bergström, D. Family forest owners' perception of management and thinning operations in young dense forests: A survey from Sweden. Forests 2020, 11, 1151. [CrossRef]

14. Gamache, S.L.; Espinoza, O.; Aro, M. Professional consumer perceptions about thermally modified wood. Bioresources 2017, 12, 9487-9501. [CrossRef]

15. Seidl, R.; Thom, D.; Kautz, M.; Martin-Benito, D.; Peltoniemi, M.; Vacchiano, G.; Wild, J.; Ascoli, D.; Petr, M.; Honkaniemi, J.; et al. Forest disturbances under climate change. Nat. Clim. Chang. 2017, 7, 395-402. [CrossRef] [PubMed]

16. Sharpe, D. Chi-square test is statistically significant: Now what? Pract. Assess. Res. Eval. 2015, 20, 8. [CrossRef]

17. Bumgardner, M.; Montague, I.; Wiedenbeck, J. Survey response rates in the forest products literature from 2000 to 2015. Wood Fiber Sci. 2017, 49, 84-92.

18. Michal, J.; Březina, D.; Šafařík, D.; Kupčák, V.; Sujová, A.; Fialová, J. Analysis of socioeconomic impacts of the FSC and PEFC certification systems on business entities and consumers. Sustainability 2019, 11, 4122. [CrossRef] 
19. Riedl, M.; Jarský, V.; Palátová, P.; Sloup, R. The challenges of the forestry sector communication based on an analysis of research studies in the Czech Republic. Forests 2019, 10, 935. [CrossRef]

20. Zubizarreta, M.; Arana-Landín, G.; Cuadrado, J. Forest certification in Spain: Analysis of certification drivers. J. Clean. Prod. 2020, 294, 126267. [CrossRef]

21. Mattila, O.; Hämäläinen, K.; Häyrinen, L.; Berghäll, S.; Lähtinen, K.; Toppinen, A. Strategic business networks in the Finnish wood products industry: A case of two small and medium-sized enterprises. Silva Fennica 2016, 3, 1544. [CrossRef]

22. Franzini, F.; Lähtinen, K.; Nyrud, A.Q.; Widmark, C.; Hoen, H.F.; Toppinen, A. Citizen views on wood as a construction material: Results from seven European countries. Can. J. For. Res. 2021, 51, 647-659. [CrossRef]

23. Brunori, A. PEFC certification in Italy, state of the art and customers recognition. In Proceedings of the Second International Congress of Silviculture, Firenze, Italy, 26-29 November 2014; Ciancio, O., Ed.; Accademia Italiana di Scienze Forestali: Firenze, Italy, 2014.

24. Paluš, H.; Parobek, J.; Vlosky, R.P.; Motik, D.; Oblak, L.; Jošt, M.; Glavonjić, B.; Dudík, R.; Wanat, L. The status of chain-of-custody certification in the countries of Central and South Europe. Eur. J. Wood Prod. 2018, 76, 699-710. [CrossRef]

25. Chen, J.; Wang, L.; Li, L.; Magalhães, J.; Song, W.; Lu, W.; Xiong, L.; Chang, W.-Y.; Sun, Y. Effect of forest certification on international trade in forest products. Forests 2020, 11, 1270. [CrossRef] 